\title{
СЕМАНТИКО-КОМУНІКАТИВНА ХАРАКТЕРИСТИКА ЛЕКСИКИ ПОЗИТИВНОЇ ОЦІНКИ В СУЧАСНІЙ АНГЛІЙСЬКІЙ МОВІ
}

\section{Олеся Татаровська}

\author{
Львівський національний університет імені Івана Франка, \\ вул. Університетська, 1, м. Львів, Україна, 79000 \\ olesya.tatarovska@lnu.edu.ua
}

\begin{abstract}
У статті розглянуто змістовий простір позитивної оцінки у сучасній англійській мові, який формується під впливом типу оцінки (морально-етичної, естетичної, інтелектуальної, соціальної, емотивної, а також оцінки фізичних та емпіричних характеристик об'єкта оцінки), об'єкта оцінки (особа/ не-особа) та номінативної площини предметів, дій та якостей, котрі потенційно можуть отримати позитивну оцінку. Встановлено, що одиниці, використовувані для позитивної оцінки морально-етичних та емоційних ознак об'єкта оцінки, корелюють з об'єктом оцінки “особа”, а одиниці, які співвідносяться із позитивною оцінкою емпіричної ознаки, корелюють з об'єктом оцінки “неособа". Увагу зосереджено на тому факті, що семантика змістової площини позитивної оцінки переважно закладається трьома основними дієслівними ідеями -“любити”, “цінувати”, “покращувати”. Доведено, що загальними для усіх частин мови номінативними тематичними сферами, за якими розподіляється лексика позитивної оцінки, виступають “любов”, “дружба”, “задоволення”, “інтелект”, “гармонічність”, “повага" та ін. Найбільша кількість тематичних площин помітна в граматичних класах прикметників та прислівників. Особливу роль у варіативності оцінки відіграють соціальні аспекти комунікації, а також стилістичне забарвлення мовних підсистем, яке впливає на характер та інтенсивність оцінки.
\end{abstract}

Ключові слова: лексика позитивної семантики, реєстр, семантичний простір, “плюс-оцінка”, меліорація, дерогативність.

Вступ. Сучасним мовознавчим студіям притаманний інтерес до комунікативних аспектів мовних явищ, який зосередив увагу лінгвістів на вивченні системнофункціональної природи мовлення, комунікативної орієнтованості всіх одиниць і категорій мовної системи, розумінні мови як діяльності, що слугує засобом вияву інтенцій індивіда. Однією з помітних тенденцій розвитку сучасного мовознавства $\epsilon$ дослідження суб'єктивного чинника в мові, способів впливу мовця на адресата, мовних механізмів породження повідомлень.

Аналіз останніх досліджень і публікацій. Особливої актуальності набули студії, у яких з'ясовується специфіка функціонування мовних одиниць з урахуванням їхніх структурно-семантичних і комунікативно-прагматичних особливостей (В. Г. Адмоні, О. В. Бондарко, В. Г. Гак, Ю. М. Караулов, О. С. Снитко, І. П. Сусов, А. П. Загнітко, О. О. Тараненко, Ф. С. Бацевич, Т. А. Космеда). У контексті такого наукового

(C) Татаровська O., 2021 
зацікавлення вагомого значення набувають дослідження оцінки як лінгвістичного феномена. Загальнофілософське осмислення оцінки доводить, що вона формується як аспект діяльності та поведінки людини в соціумі та є своєрідною характеристикою об'єкта через призму відношення до нього суб'єкта.

Проблема оцінки розглядається в сучасному мовознавстві як один із найважливіших аспектів опису змістовного боку мовних одиниць [1-10]. 3 огляду на таку релевантність аксіологічних студій, у цій статті пропонується аналіз семантичних та прагматичних особливостей лексики позитивної оцінки сучасної англійської мови. Дослідження здійснено на матеріалі англомовних словників та художніх текстів другої половини $\mathrm{XX}$ століття (див. Словники та Список використаних джерел).

Методологія дослідження. У дослідженні застосовано такі методи, як описовий, прагмасемантичної інтерпретації, аналіз словникових дефініцій, контекстуальноінтерпретаційний та елементи дискурс-аналізу.

Застосування описового методу було спрямоване на накопитчення спостережень (з інтуїтивним виділенням мовних одиниць і зведенням їх у сукупності), зіставлення, узагальнення та інтерпретацію. Метод прагмасемантичної інтерпретації забезпечив виокремлення прийомів реалізації досліджуваного явища.

Аналіз словникових дефініцій дав змогу виявити значну кількість лексичних одиниць, у змістовій структурі яких є вказівка на те, що означуваний словом предмет чи явище оцінюється позитивно. Про це свідчить наявність семи “good”, яка слугує універсальним маркером “плюс-оцінки”. Додатковими маркерами “плюс-оцінки” можна вважати наявність у дефініції одного з синонімів прикметника "good", які можна виділити з його дефініцій у Великому Оксфордському Словнику: 1) useful or sound; 2) morally excellent; 3) kind, benevolent; 4) friendly, favourable; 5) pleasant або pleasing; 6) advantageous; 7) skilled, competent, clever; 8) adequate, sufficient, satisfactory; 9) desirable, right, proper.

За допомогою контекстуально-інтерпретаційного методу мовні явища вивчалися 3 орієнтацією на комунікативний макроконтекст та інші компоненти дискурсу. Елементи дискурс-аналізу було використано для розгляду соціального контексту, в якому здійснюється мовленнєва діяльність, установлення взаємозв'язку між мовним кодом у спілкуванні й соціальними, психічними та культурними процесами.

Результати дослідження та їхнє обгрунтування. Лексика позитивної оцінки слугує засобом мовної номінації однієї частини семантичного простору оцінки, яку протиставляють іншій частині цього простору, що містить дерогативні номінанти, тобто засоби вираження зі знаком "мінус".

Як відомо, конотативні мікроелементи часто відзначаються в лексикографічній практиці за допомогою спеціальних поміток. Проведений аналіз засвідчує те, що в англійських словниках число поміток, що вказують на наявність в значенні слова позитивної оцінки, є невеликим. Помітками виступають вказівники на кшталт “а word of appreciation", “a word of endearment" чи “affectionate”, котрі трапляються з невеликою кількістю слів, переважно іменників, наприклад: pretty - (apprec) causing admiration for

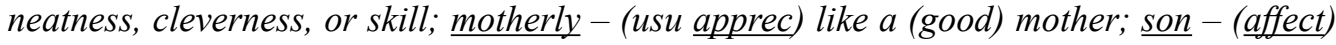
form of address to a boy or younger man (L). 
Помітки позитивної оцінки наводяться і в дефініціях деяких стійких словосполучень, наприклад: There's a good boy -used to give appreciation or encouragement $(\mathrm{H})$.

Усього в досліджуваному матеріалі (при суцільній вибірці з 10 словників) виділені 138 одиниць, які марковані такими помітками. Серед них 62 іменники, 48 прикметників та 28 прислівників.

Виконане дослідження продемонструвало, що змістовий простір позитивної оцінки формується двома типами слів. У першому типі слів маркер позитивної оцінки безпосередньо присутній у словниковій дефініції, як-от: sagacious - showing good judgement, common sense, intelligence $(\mathrm{H})$. Такі слова становлять $42 \%$ від загальної кількості одиниць (серед них прикметників - $14 \%$, прислівників - $14 \%$, іменників $11,5 \%$, дієслів $-2,5 \%$ ).

У другому типі слів маркер “плюс-оцінки” виявляється тільки шляхом послідовного перетворення словникової дефініції, наприклад: convenience -the quality of being convenient or suitable; freedom from difficulty or worry; right for the purpose or occasion; best in view of the circumstances $(\mathrm{H})$.

Відібраний у процесі дослідження корпус англійської лексики позитивної оцінки становить 2426 одиниць. Позитивно-оціночна лексика нерівномірно розподіляється за частинами мови: ми виокремили 868 прикметників, 868 прислівників, 476 іменників та 214 дієслів. Основну частину ЛПО складають прикметники, що пов'язано з характером їхнього категоріального значення - позначенням ознак предмета, закріплення котрих в номінації вже $є$ потенційною вказівкою на оцінку. Позитивно-оціночні прислівники в багатьох випадках пов'язані з прикметниковими словотвірними стосунками, i, як наслідок, - загальні розряди класифікації за об'єктом оцінки та за змістовими галузями в прикметників та прислівників повністю збігаються. Отже, зміна значення одиниці залежно від приналежності до частини мови, які пов'язані словотвірними стосунками, у більшості випадків не впливає на характер оцінки. Позитивно-оціночні іменники та дієслова значно менш численні порівняно з прикметниками та прислівниками “плюсоцінки”, їхня семантика має більш загальний характер.

Прикметник як частина мови, яка називає ознаку предмета, слугує головно засобом позначення і позитивно оцінних ознак чи якостей, оскільки, як правило, оцінка предмета здійснюється залежно від наявності у нього будь-якої необхідної, корисної чи приємної ознаки чи якості.

Більшість “плюс-оцінних" прикметників - це прикметники інтелектуальної та змішаної (інтелектуально-емотивної) оцінки (94, 6\%). Для прикметників позитивної оцінки притаманна градація оцінки, при цьому одиниці “плюс-оцінки” знаходяться переважно на двох “сходинках" шкали градації, розрізняючи “нормативний” та “найвищий” ступінь позитивного. Крім того, в процесі дослідження ми виявили групу одиниць “плюс-оцінки", які мають відому універсальність, тобто дотичність до різноманітних типів об'єктів оцінки. Ми не сприймаємо універсальність в абсолютному сенсі, оскільки практично неможливо знайти в мові оцінне слово, яке можна було б застосувати до всіх об'єктів оцінки, оскільки інколи низку явищ неможливо кваліфікувати за принципом “добрепогано”. Ми вважаємо одиницю універсально оцінною, якщо вона співвідноситься 3 більшістю виділених у процесі дослідження типів об’єктів оцінки. 
До універсально оцінних, окрім прикметника good, відносимо, наприклад: splendid-magnificent, gorgeous, sumptuous, glorious, brilliant, fine, excellent, very good (COD). Порівняймо, приміром, синтагми, отримані зі словників: Splendid palace, gift, achievement, victory (COD); splendid idea, sunset, jewelry, dinner $(\mathrm{H})$; splendid efflorescence, city, quality (WS); splendid sunrise, banquet, career (F).

Аналогічними за своєю універсальною дотичністю є одиниці admirable, excellent, fine, good, magnificent, marvellous, perfect, pleasant, remarkable, superb, wonderful та ін. Кількість таких слів становить 8\% від загальної кількості прикметників позитивної оцінки.

Виділяємо такі об’єкти оцінки: особа, особа та ії діяльність, неживе предметне явище, абстрактне явище та емоційний стан. Найчисельнішою є група позитивнооцінних прикметників, які співвідносяться з об'єктом оцінки “особа та її діяльність” та становлять 58, 7\% від загальної кількості прикметників “плюс-оцінки”. За характером ознаки як об'єкта оцінки виділяємо прикметники, які позитивно характеризують морально-етичну, емоційну (happy), інтелектуальну (wise), естетичну (elegant), соціальну (patriotic), фізичну (healthy), емпіричну (tasty) ознаки об'єкта оцінки. Найчисленнішими прикметниками “плюс-оцінки” $є$ ті, які співвідносяться з морально-етичною ознакою як об’єктом оцінки: вони становлять 60 \% від загальної кількості позитивно-оцінних прикметників.

Номінативно закріплена в семантиці прикметників вказівка на позитивну оцінку позначуваного формує три основні змістові площини: якості речі (useful, comfortable, appropriate), якості людини (разом із фізичними якостями: handsome, healthy тощо; інтелектуальні якості: clever, intelligent тощо; та морально-етичні якості: honest, honourable тощо), а також якості людини, які виявляються по відношенню до інших людей (kind, compassionate тощо).

Варто зауважити переважання “плюс-оцінних" прикметників, які характеризують людину. Прикметники, які описують позитивні якості речі, $є$ помітно менш чисельними та представлені меншою кількістю груп. Найчисельнішою є група “гарна зовнішність”, найменшою кількістю одиниць представлена група “вартий уваги”, “довірливий”.

Як об’єкт оцінки прислівника зазвичай виступає дія, що пов’язано з їхньою функцією як частини мови. Окрім характеристики дії чи/та процесу, в семантиці прислівника зберігається вказівка на об'єкт оцінки того прикметника, з яким він пов'язаний словотвірними зв'язками (admirably). 3 огляду на це, загальні розряди класифікації за об' єктом оцінки та змістовою площиною в прикметників та прислівників майже повністю збігаються.

В іменників позитивної оцінки в якості об'єкта оцінки виступають особа, неживий предмет, опредмечена якість чи ознака, стан, дія, емоції та почуття. Найчисленнішими є іменники, які співвідносяться з об'єктом оцінки “особа”: 24 \% від загальної кількості іменників “плюс-оцінки”. За характером ознаки як об'єкта оцінки виділяємо іменники, які позитивно оцінюють морально-етичні (benevolence), емоційні (admiration), інтелектуальні (aptness), соціальні (justice), естетичні (grace), фізичні (bloom), емпіричні ознаки (euphony). Помітними є іменники, які співвідносяться 3 морально-етичною ознакою як об'єктом оцінки та становлять 57 \% одиниць від загальної кількості іменників 
“плюс-оцінки”. Змістовий простір іменників позитивної оцінки представлений меншою кількістю груп (серед яких переважають групи “доброта”, “вірність”).

У дієслів позитивної оцінки як об'єкт оцінки виступають: відношення до особи та не-особи, зміна (покращення) фізичного стану об'єкта (особи чи не-особи); емоційний стан суб'єкта, який викликає певний об'єкт; вияв позитивного ставлення суб' єкта до об'єкта (особи), об’єктивований у вигляді фізичної дії; зміна якості об’єкта дії; позитивний емоційний стан деякого об'єкта дії, котрий викликаний деякою дією суб'єкта. Найчисленнішими є дієслова, що обирають як об'єкт оцінки “зміну якості об'єкта дії”: вони становлять 22,4 \% від загальної кількості дієслів “плюс-оцінки”. За характером ознаки як об'єкта оцінки виділяємо дієслова, які позитивно оцінюють морально-етичну (reform), емоційну (like), інтелектуальну (reason), соціальну (uplift), естетичну (harmonize), фізичну (recover), емпіричну (relish) ознаки. Дієслова, що співвідносяться 3 морально-етичною ознакою як об'єктом оцінки, становлять 42 \% від загальної кількості дієслів “плюс-оцінки”. Змістова площина позитивнооцінних дієслів представлена меншою кількістю груп порівняно з прикметниками, прислівниками та іменниками. Це групи “любити”, “цінувати”, “покращувати”, серед яких кількісно домінує група “любити”. Позитивно-оцінні дієслова мають більш узагальнений характер порівняно з прикметниками, прислівниками та іменниками “плюс-оцінки".

Аналіз матеріалу показав, що позитивна оцінка $є$ номінативним центром в семантиці переважної більшості одиниць, відібраних для аналізу. У якості головного оцінне значення виступає у 90 \% прикметників та прислівників, у 83 \% іменників та $90 \%$ дієслів. Той факт, що у слів різних частин мови позитивну оцінку помічаємо в основному значенні, свідчить про відносно самостійний характер площини позитивної оцінки у сучасній англійській мові.

Оцінні слова, які належать до різних частин мови, часто формують словотвірні ряди, основу яких складають оцінні прикметники. Такі оцінні ряди можуть входити до більших дериваційних гнізд, в складі яких виявляємо як і оцінні, так і неевалютивні лексичні одиниці. У деяких випадках до складу гнізд можуть входити різнополюсні оцінні одиниці.

Оцінний компонент закріплюється в значенні слів у результаті його регулярного відтворення в процесі мовної комунікації. Природно, що аналіз мовного матеріалу виявляє велику кількість текстів, у змісті яких реалізується позитивна оцінка ситуації, котра описується, або ж окремих ії компонентів. Характер такої реалізації значною мірою визначається семантикою оцінних слів. Водночас наявність у слова оцінного значення ще не розкриває усієї складної картини вираження оцінки в тексті. У конкретних умовах мовної реалізації позитивна оцінка може підсилюватися чи послаблятися, різноманітними способами взаємодіяти з іншими елементами змісту, змінювати свій знак, зазнавати інших модифікацій.

Дослідження способів вираження оцінки у мовній комунікації дозволяє не лише уточнювати характер реалізації оцінних компонентів лексичних одиниць, але й виявляти закономірності формування оказіональної оцінки, коли позитивна чи негативна оцінка виражається за допомогою оцінно нейтральних слів. 
Аналіз текстового матеріалу дозволяє нам також виявити умови та причини зміни характеру та інтенсивності оцінки, що виражається, та визначити контекстуальні та екстралінгвістичні фактори, які модифікують мовну оцінку в кожному окремому випадку. Такий аналіз має на меті всебічне врахування прагматичних, психолінгвістичних та соціолінгвістичних аспектів мовної комунікації, оскільки, наприклад, слова політичної лексики (conservative, liberal, centrist, reactionary, radical тощо) є “суб' єктивними наліпками" внаслідок того, що їх оцінна ознака змінюється залежно від ідеології мовця.

Розглядаючи соціальну детермінованість мовних явищ варто, перш за все, враховувати такий компонент ситуації спілкування, як “учасники комунікативного акту”. Щодо стосунків між комунікантами, то беремо до уваги передусім їхній статус та рольові стосунки. Орієнтування на слухача, на його статусні характеристики виявляються особливо чітко під час використання емоційно-оцінних, стилістично маркованих номінацій, вибір яких регулюється соціально-етичними нормами мовної поведінки прийнятими у суспільстві, невиконання котрих викликає несхвалення мовної спільноти.

У текстовій реалізації позитивна оцінка може уточнюватися за ознакою, що безпосередньо оцінюється; підсилення оцінки забезпечується використанням інтенсифікаторів та нанизуванням декількох одиниць позитивної оцінки, наприклад: "Dearest beloved darling Kitty!" [12, c. 82]; "Look! What a perfectly good up-to-the-minute handset!" [13, c. 91].

Нейтралізація та послаблення позитивної оцінки досягається використанням заперечення позитивно оцінюваної ознаки або ж заперечення його інтенсифікації: not very good, not exceptionally beautiful; It's too exquisite for my taste. Нейтралізація та дерогативація позитивної оцінки досягається використанням фактору “невідповідності” позитивно-оцінної одиниці та ситуації, для опису якої вона використовується, наприклад: She looked at me appealingly. "Joe, you are tired. You've had something to drink. Wait until morning at least, dear". Brown snorted. "Dear!" he said. "He's leaving her and she calls him dear! Let the bastard kill himself and good radiance!” [16, c. 250].

Основними способами оказіонального формування позитивної оцінки в контексті $€$ меліорація негативної оцінки та індукування позитивної оцінки у слів, нейтральних в оцінному плані. Для заміни знаку використовується контекст, який містить меліоративну оцінку. Важливу роль відіграє також “ключ” (тональність), в якому вибудовується мовлення мовця: She covered my face with kisses ... "You beautiful brute”, she said. [15, c. 106]; "Forget it, darling idiot". He pulled her to her feet and kissed her cheek lightly. "Darling morbid idiot. Forget Rosemary. Only think of me" [14, c. 80].

Реальне використання слів у мовному спілкуванні визначається не тільки його власним значенням та його місцем в семантичному просторі, але й комунікативноситуативними факторами, які формують умови комунікації. Мовець відбирає лексичні одиниці, враховуючи оточення та учасників комунікації, тобто враховує "реєстр" комунікації.

Термін “реєстр” використовується на позначення мовної підсистеми, яка забезпечує підтримку спілкування в певній комунікативній ситуації згідно з соціальними ролями комунікантів, їх рольовими позиціями та взаємовідносинами. У нашому дослідженні 
ми врахували п'ять реєстрів: 1) урочистий, 2) формалізований (службове спілкування), 3) діловий, 4) фамільярний, 5) сімейно-побутовий.

Проведене нами дослідження показує, що на вибір позитивно-оцінних одиниць також впливають такі чинники, як: 1) атмосфера спілкування, 2) комунікативні ролі учасників в рамках спілкування, 3) глобальна мета спілкування, 4) спосіб спілкування, 5) ступінь відпрацювання мовлення.

Кожний реєстр певною мірою впливає на вибір позитивно-оцінної лексики, яка функціонує у всіх виділених реєстрах. Помічено тенденцію до надання переваги нейтральній чи негативно-оцінній лексиці у високих реєстрах та до переважання у них інтелектуальної оцінки, а у низьких реєстрах - емотивної оцінки. Наприклад, у наступному контексті сімейно-побутовий характер ситуації спілкування обумовлює появу трьох позитивно-оцінних одиниць (dear, my love, my Crystal baby) у відносно короткій репліці: “And now, dear”, her mother said, "tell me how it was. Tell me everything, my love. Did you make some new friends, my Crystal baby?” [11, c. 83].

Висновки та перспективи подальших досліджень. Змістовий простір позитивної оцінки в сучасній англійській мові формується під впливом типу оцінки (моральноетичної, естетичної, інтелектуальної, соціальної, емотивної, а також оцінки фізичних та емпіричних характеристик об'єкта оцінки), об'єкта оцінки (особа/ не-особа) та номінативної площини предметів, дій та якостей, які потенційно можуть отримати позитивну оцінку. Одиниці, використовувані для позитивної оцінки морально-етичних, емоційних ознак об'єкта оцінки, корелюють з об'єктом оцінки “особа”, а одиниці, які співвідносяться із позитивною оцінкою емпіричної ознаки, корелюють з об'єктом оцінки “не-особа".

Оцінне значення домінує у семантиці проаналізованих лексичних одиниць різної частиномовної приналежності, що вказує на відносно самостійний характер площини позитивної оцінки в сучасній англійській мові.

Семантика змістової площини позитивної оцінки зазвичай закладається трьома основними дієслівними ідеями “любити”, “цінувати”, “покращувати”. Загальними для усіх частин мови номінативними тематичними сферами, за якими розподіляється лексика позитивної оцінки, виступають “любов”, “дружба”, “задоволення”, “інтелект”, “гармонічність”, “повага” та ін. Найбільша кількість тематичних площин помічаємо в прикметників та прислівників.

Оцінка залежить від комунікативної ситуації, в якій вона використовується, та контекстного оточення. Особливу роль у варіативності мовленнєвих оцінок відіграють соціальні аспекти комунікації, а також стилістичне забарвлення задіяних мовних підсистем, що впливає на характер та інтенсивність оцінки.

Перспективу подальших досліджень вбачаємо у співвідношенні та співставленні площин одиниць негативної та позитивної оцінки. 


\section{СПИСОК ВИКОРИСТАНОЇ ЛІТЕРАТУРИ}

1. Арутюнова Н. Д. Аномалии языка (К проблеме языковой “картины мира”). Bonросы языкознания. 1987. № 3. С. 3-11.

2. Арутюнова Н. Д. Коммуникативная функция и значение слова. Филологические науки. 1973. № 3. С. 42-54.

3. Арутюнова Н. Д. Номинация, референция, значение. Языковая номинация. Общчие вопросы / под. ред. Б. А. Серебренников и др. Москва : Наука, 1977. С. 188-206.

4. Арутюнова Н. Д. Типы языковых значений. Оценка. Событие. Факт. Москва : Наука, $1988.338 \mathrm{c}$.

5. Бігунова Н. О. Від позитивного судження до комунікативного висловлювання : монографія. Одеса : КП ОМД, 2017. 580 с.

6. Вольф Е. М. Функциональная семантика оценки. Москва : Наука, 1985. 228 с.

7. Писанова Т. В. Национально-культурные аспекты оценочной семантики (эстетические и этические оценки): дис. ... д-ра филол. наук : 10.02.19/ Московский государственный лингвистический університет. Москва, 1997. 393 с.

8. Соловйова Л. Ф. Вираження аксілогічних категорій у сучасній англійській мові (атрибути, предикативи і релятиви оцінки): дис. ... канд. філол. наук : 10.02 .04 / Житомирський державний педагогічний університет імені Івана Франка. Житомир, 2000. $165 \mathrm{c}$.

9. Телия В. Н. Коннотативный аспект семантики номинативных единиц. Отв. ред. А. А. Уфимцева. Москва : Наука, 1986. 143 с.

10. Шкіцька І. Ю. Маніпулятивна стратегія позитиву в українській мові: дис. ... канд. філол. наук : 10.02.01 / Тернопільський національний економічний університет. Тернопіль, 2012. $484 \mathrm{c}$.

\section{СПИСОК ВИКОРИСТАНИХ ДЖЕРЕЛ}

11. Greene G. May We Borrow Your Husband. London : Pan Books Ltd., 1973.

12. Grey B. Proxy Wedding. London : Pan Books Ltd., 1982.

13. Murdoch I. A. Word Child. London : Pan Books Ltd., 1975.

14. Roth Ph. Letting Go. New York : Routledge, 1967.

15. Snow C. P. The New Men. London : Penguin Books, 1962.

16. Stone I. The Agony and the Ecstasy. New York : Routledge, 1963.

\section{Словники}

L - Longman Lexicon of Contemporary English. Longman Group Ltd., 1981.

$\mathrm{H} \quad-$ Oxford Advanced Learners Dictionary of Current English. New Edition. Oxford University Press, 2002.

F $\quad-$ Synonyms, Antonyms and Prepositions. Ed. by J. C. Fernarld.

L.H.D. - Completely Revised. N. Y., 1980.

COD - The Concise Oxford Dictionary of Current English. Sixth Edition. Oxford University Press, 1998.

OED - The Oxford English Dictionary on Historical Principles. Vol. I XII. Oxford : Claredon Press, 1933. A Supplement to the ... Oxford : Claredon Press. Vol. I, 1972; Vol. II, 1976.

WS - Webster's Dictionary of Synonyms. Springfield (Mass) : Merriam, 1952. 


\section{REFERENCES}

1. Arutiunova N. D. Anomaliyi yazyka (K problem yazykovoy "kartiny mira"). Voprosy yazykoznaniya. 1987. № 3. S. 3-11.

2. Arutiunova N. D. Komunikativnaya funktsiya i znacheniye slova. Filologicheskiye nauki. 1973. № 3. S. 42-54.

3. Arutiunova N. D. Nominatsiya, referentsiya, znacheniye. Yazykovaya nominatsiya. Obshchiye voprosy. Pod. red. B. A. Serebrennykova i dr. Moskva : Nauka,1977. S. 188-206.

4. Arutiunova N. D. Tipy yazykovyh znacheniy. Otsenka. Sobytiye. Fakt. Moskva : Nauka, 1988. $338 \mathrm{~s}$.

5. Bihunova N. O. Vid pozytyvnoho sudzhennia do komunikatyvnoho vyslovliuvannia : monohrafiia. Odesa : KP OMD, 2017. $580 \mathrm{~s}$.

6. Volf Ye. M. Funktsionalnaya semantika otsenki. Moskva : Nauka, 1985. $228 \mathrm{~s}$.

7. Pisanova T. V. Nacionalno-kulturnye aspekty ocenochnoy semantiki (esteticheskiye i eticheskiye ocenki): dis. ... d-ra filol. nauk : 10.02.19 / Moskovskiy gosudarstvennyi lingvisticheskiy universitet. Moskva, 1997. $393 \mathrm{~s}$.

8. Soloviova L. F. Vyrazhennia aksilohichnykh katehoriy u suchasniy anhliiskiy movi (atrybuty, predykatyvy i reliatyvy otsinky): dys. ... kand. filol. nauk : 10.02.04 / Zhytomyrskyi derzhavnyi pedahohichnyi universytet imeni Ivana Franka. Zhytomyr, 2000. 165 s.

9. Teliya V. N. Konnotativniy aspect semantiki nominativnykhy edinits / otv. red. A. A. Ufimtseva. Moskva : Nauka, 1986. 143 s.

10. Shkitska I. Yu. Manipuliatyvna stratehiya pozytyvu v ukrainskiy movi: dys. ... kand. filol. nauk : 10.02.01 / Ternopilskyi natsionalnyi ekonomichnyi universytet. Ternopil, 2012. $484 \mathrm{~s}$.

\section{SOURCES}

11. Greene G. May We Borrow Your Husband. London : Pan Books Ltd., 1973.

12. Grey B. Proxy Wedding. London : Pan Books Ltd., 1982.

13. Murdoch I. A. Word Child. London : Pan Books Ltd., 1975.

14. Roth Ph. Letting Go. New York : Routledge, 1967.

15. Snow C. P. The New Men. London : Penguin Books, 1962.

16. Stone I. The Agony and the Ecstasy. New York : Routledge, 1963.

\section{DiCTIONARIES}

L - Longman Lexicon of Contemporary English. Longman Group Ltd., 1981.

$\mathrm{H}-$ Oxford Advanced Learners Dictionary of Current English. New Edition. Oxford University Press, 2002.

F - Synonyms, Antonyms and Prepositions. Ed. by J. C. Fernarld.

L.H.D. - Completely Revised. New York, 1980.

COD - The Concise Oxford Dictionary of Current English. Sixth Edition. Oxford University Press, 1998.

OED - The Oxford English Dictionary on Historical Principles. Vol. I XII. Oxford : Claredon Press, 1933. A Supplement to the ... Oxford : Clarendon Press. Vol. I, 1972; Vol. II, 1976.

WS - Webster's Dictionary of Synonyms. Springfield (Mass) : Merriam, 1952. 


\title{
SEMANTIC AND COMMUNICATIVE CHARACTERISTICS OF LEXEMES OF POSITIVE ASSESSMENT IN MODERN ENGLISH
}

\section{Olesya Tatarovska}

\author{
Ivan Franko National University in Lviv, \\ 1, Universytetska Str., Lviv, 79000, Ukraine \\ olesya.tatarovska@lnu.edu.ua
}

The article deals with the content space of positive assessment in modern English, which is formed under the influence of the type of assessment (moral and ethical, aesthetic, intellectual, social, emotional as well as the assessment of physical and empirical characteristics of the evaluation object), the object of evaluation (person / non-person), and the nominative plane of subjects, actions and qualities that can potentially be positively assessed. The units used to positively assess moral, ethical, and emotional characteristics of the evaluation object correlate with the object of the "person" assessment, and units that correlate with a positive assessment of empirical features correlate with the object of the "non-person" assessment. The study reported in the article was conducted at the lexical and semantic levels.

Semantics of the content plane of positive assessment is mainly laid down by three main verb ideas of "love", "appreciate", "improve". Common for all parts of nominative thematic spheres are "love", "friendship", "pleasure", "intelligence", "harmonicity", "respect" and others. The largest number of thematic planes can be noticed in adjectives and adverbs. Analysis at the lexemic level proved that multivalued words, in which all values would be evaluated, are rather few. In most cases, the evaluative value appears in the vocabulary of positive evaluation as the main one. Only in a small number of lexemes, semantic variants are formed in the process of development of semantic structure of lexemes.

Within the semantic structure, lexemes are sometimes combined by semantic variants, which have an opposite score. All this indicates that the assessment in a number of cases is secondary: it is formed as an indication of the secondary characteristcs of the sign. If the score is at the "top" of a lexeme's semantics, it can usually be applied to a large number of disparity characteristics of various objects.

The assessment depends greatly on the situation in which it is used, that is, on the contextual environment and the nature of the speech act. Sociolinguistic aspects of communication as well as expressive stylistic color of the speech act play a special role in the variability of speech assessments.

Adjectives that express the assessment and indicate any sign of the subject more often than other parts of the language are independently used to form the evaluative context. However, a significant number of estimated nouns and verbs rarely appear in the context of isolation. These words require the explication of the estimated signs of the reference, which creates the possibility of sharing the evaluated words of different parts of the language in the same context.

Key words: vocabulary of positive semantics, register, semantic space, "plus-score", melioration, derogativeness. 